\title{
Birds observed and collected on Board or on Land during the Voyage between Kobe, Singapore and Java, 1929.
}

By

Nagamichi Kuroda, D. Sc.

I have sailed for Java via Singapore leaving Kobe on the 25th April, 1929. During the voyage I have often observed and collected a few species of birds on board S.S. "HarunaMaru" between Kobe and Singapore. It is very interesting and worthy to note here for investigating the migration of the birds obtained on sea, and distribution of land birds

The foilowing birds have seeu or obtained:-

Larus ridibundus (? sibiricus). The most of the gulls in breeding plumage of black-headed. About 40-50 individuals were seen in the Kobe Harbour (25. iv.). A few numbers of the species were also met with near the islaud of Awaji.

Larus argentatus vegae? Only one example was seen near the island of Awaji (25. iv.).

Milvus l. lineatus. Two on wing were observed in the Kobe Harbour (25. iv.).

Common species of garden birds in Shanghai (29.iv.).

Corvus coronoides colonorum. Two or three were seen at garden of Majestic Hotel.

Pica pira sericea. Several individuals were seen in gardens and some nests were observed.

Cyanopica cyana swinhoei. A few birds were observed in the Jessfield Park. Very tame.

Eophona migratoria pulla. A pair of this bird were seen 
in the Jessfield Park. Also very tame.

Passer m. saturatus. Less numerous in the same park.

Sutlora webbiana webbiana. Not common (?), but few was secn in a garden .

Pycnonotus sinensis (? sinensis or ? septentrionalis). Common in the Jessfield Park.

Horornis cantans canturians. A note of this bird was heard in the same Park.

Turdus merula mandarinus. Rather common in the Jessfield Park where it uttered very melodious notes.

Hirundo rustica gutturalis. Common in the Jessfield Park.

Dryolates major cabanisi. Only one example on wing was seen.

Streptopelia c. frigoris (or ? chinensis). A few voices of this dove wore heard in the Jessfield Park and some were seen in a garden.

Near Woosung I saw five crows and a few swallows (30. iv.).

Between Shanghai and Formosa Strait, I obtained or observed the following species of birds on the 1st May :-

Glottis nebularius. An example ( $q$ ad.) of the wader came on board and captured at 8-10 a.m. (15 miles South-east of Hieshan Islands (黑山列島), Lat. $28^{\circ} 41^{\prime}$ N., Long. $122^{\circ} 21^{\prime}$ E.). No other individuals were seen.

Limosa lapponica baueri. An adult male was obtained on board at 9-25 a.m. (29 miles South-west of Hieshan Islands, Lat. $28^{\circ} 24^{\prime}$ N., Long. $122^{\circ} 12^{\prime}$ E.). None of the same species came.

Charadrius l. leschenaultii. One came on board together with Glottis and Limosa just mentioned as above.

Butorides striatus ? javanicus. One came newr the board, 
a.m.

Motacilla flava similima. Two adult birds came, a.m.

Monticola solitaria subsp.? One female came on board, a.m.

Emberiza rutila. An adult male was captured at 4-10 p.m. (60 miles off Wen-chau-fu (溫州府), Lat. $27^{\circ} 13^{\prime}$ N., Long. $\left.121^{\circ} 15^{\prime} \mathrm{E}.\right)$.

Anthus trivialis ?hodgsoni. One came in the evening.

Astur ? soloensis. One came in the evening, and it caught a small bird on a mast.

Falco peregrinus ? calidus. Two came and rested on masts in the evening.

On the 3rd May we reached at Hongkong and I called the City Hall Museum, where I saw the following specimens with interests :- 4 Diomedea albatrus * (Hongkong), 1 Nipponia nippon, 1 Cygnus b. jankowskii (Shanghai), 1 Chaulelasmus streperus (Shanghai), 1 Tadorna tadorna (Swatow), 1 Dendrocygna javanica (Hainau), etc.

Common species of birds of Hougkong olserved are as follows (3.v.):-

Corvus sp. (coronoides-group?). One at the foot of the peak and three near the Repulse Bay.

Urocissa e. erythrorhyncha. One was met with near Repulse Bay.

Aethiopsar c. cristatells. One near Victoria Peak and three near the Repulse Bay.

$P$. sser $m$. taivanensis. A few in the city.

Matacilla alba ? leucopsis. One was seen near Victoria Peak.

Zosterops p. simplex. One in the Botanic Gardens.

* Labeled as Diomedea "exulans," 
Lanius s. schach. One near the peak and another near the Ropulse Bay.

Pycnonotus atricapillus. Two or three wero scen near the peak.

Otocompsa emeria jocosa. Two in the Botanic Gardens.

Copsychus saularis prosthopellus. Two examples were seen in the Botanic Gardens.

Hirundo $r$ gutturalis. Only one on wing was seen near the peak.

Streptopelia c. chinensis. Three in the Botanic Gardens.

Milvus l. lineatus. Two on wing were seen at the peak (3. v.), and-one on the coast of Hongkong (4.v.).

Near Hongkong in the South China Sea, the under-mentioned two birds were obtained (4.v.) :-

Lanius cristatus lucionensis, $q$ ad. Captured at $10-00$ p.m. (135 miles South-west of Hongkong, Lat. $20^{\circ} 20^{\prime}$ N., Long. $112^{\circ} 57^{\prime}$ E.).

Motacilla cinerea caspica, $q$ ad. (hiem.-aest.). Obtained at the same time as above mentioned.

The followiug birds were observed on the 5th May:-

Puffinus sp. Four cume rather near the boat, $6-45 \mathrm{a} . \mathrm{m}$.

Sula sula rubripes. An adult came very near the boat, 3 50 p.m.

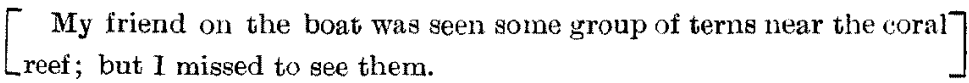

Two passerine birds (buntings ?) came on board, 7-30 a.m. (7. v.).

On the 8th May, I demonstrated the above five birds which were obtained on board and skinned myself. Naturalists in the same boat, Dr. Vaughin, Dr. Cooke, Dr. Frederic V. Coville, and Dr. D. Black have presented there with very much interest, as they were the good examples explaining the 
migration of birds.

We renched to Singapore pier on the evening of the same day.

Common garden as well as city birds in the Island of Singapore observed are as follows (9. v.).:-

Passer m. malaccensis. A few examples were seen at Leonie Hill.

Prdda oryzivora. One was seen at the same place.

Munia m. maja. A small group was observed in the Botanic Gardens.

Pycnonotus goiavier anolis. Common in the Botanic Gardens and at Leonie Hill.

Copsychus saularis musicus. Seen in the Botanic Gardens and at Leonie Hill.

Micropus affinis subfrucatus. Very common breeding birds in the busy city of Singapore.

Geopelia s. striata. Common but not numerous at Leonie Hill.

I examined several interesting specimens in the Baffles Museum and saw many valuable cage birds in the market and also in the collection of Basapa in the city and at Pongol, and de Souza Brothers's collection of cage birds and mummals.

The next day (10. v.) I drove 17 miles from Singapore to Johore, where I saw the following birds:-

A few of Passer m. malaccensis, 1 Pycnonotus goiavier analis, 1 Hirundo r. gutturalis, 1 Halcyon chloris armstrongi (humii), and 1 Streptopelia c. forresti ( $t i$ rina).

In the afternoon of the same day, I went on board a Dutch boat S.S. "Melchior-Treub" leaving Tanjong Pagar pier, Singapore, for Java. Then I saw one Cuncuma leucogaster and two Haliastur indus intermedius at the pier. 
At 10-35 a.m. (11. v.), we arrived at the coast of the Island of Banka where I saw a few Hirurdo r. gutturalis and 4 Haliastur i. intermedius.

On the 12th May, our boat entered into the Tanjong Priok near Batavia, where I found three Haliastur i. intermedius and a large group of Collocalia esculenta linchi nested on the roof of the Custom House.

On the way home from Batavia I took S.S. "Plancius" to Singapore and thence S.S. "Fushimi-Maru" to Kobe. After learing Batavia I was taken sick and laying on the bed over a week so that I missed to observe the birds except the following ones:-

Haliastur indus intermedius. Only one seen at Tanjong Priok, Batavia (15. vi.), one at Banka (16. vi.) and one at Tanjong Pagar, Singapore (17. vi.).

Phalacrocorax niger (javanicus). One seen off Tanjong Priok (15. vi.).

Fregata sp. One example was seen between Banka and Singapore (16. vi.)

Puffinus sp. Same (16. vi.).

At the Leonie Hill, Singapore, I observed wholly same number of the species above mentioned, except that one example of Rhipidura javanica which newly came in sight (18. vi.).

At Hongkong (23. and 24. vi.) I stayed on board.

On the 26th June, I saw one Sula sula rulripes in grey phase or immature? (6-30 a.m.).

At Shanghai (27. and 28. vi.) I stayed aiso on board then I saw a few Passer $m$. saturatus, two Hirundo daurica ? nipalersis and a great flock of Corvus furugilegus pastinator? on roof (645 p.m., 27. vi.). 
An example of Hirundo 1 , gu'turalis came near on board (6-50 p.m., 28, vi.).

No birds came in my sight from 29 th June to 1st July, when our boat arrived at Kobe. 